\title{
EXPLORING THE CONSTITUTION OF ENVIRONMENTAL EDUCATION AS SITUATED, CRITICAL PROCESSES OF LEARNING AND CHANGE: A COLLABORATIVE SYNTHESIS ACROSS DIVERSE REGIONAL CONTEXTS
}

\author{
Chris Eames ${ }^{1}$ \\ Per Sund ${ }^{2}$ \\ Maria Inês Gasparetto Higuchi ${ }^{3}$ \\ Haydée Torres de Oliveira ${ }^{4}$ \\ Rob O'Donoghue ${ }^{5}$
}

\begin{abstract}
This article offers a set of unique vignettes or stories that attempt to illustrate examples of critical approaches to environmental education (EE) in diverse contexts. It draws from the experiences of five environmental educators in four different regions of the world. We detail the history of the emergence of critical consciousness in education in Brazil, and its application in a Brazilian region, then move to examples of critical educational responses to oppression in New Zealand and Zimbabwe, before closing with a critical examination of innovative teaching and research in Europe. Through this breadth of endeavour, we identify commonalities across these contexts such as the importance of participatory action and research to examine peopleenvironment relations, particularly as constituted by indigenous peoples, and to interpret realities in ways that empower through learning-led social-ecological change. We argue that this critical approach can foster emancipation through individual and collective learning in EE processes within very different contexts.
\end{abstract}

Keywords: Critical approaches. Environmental education. Diverse contexts.

EXPLORANDO LA CONSTITUCIÓN DE EDUCACIÓN AMBIENTAL Y LOS PROCESOS CRÍTICOS DE APRENDIZAJE Y CAMBIO: UNA SÍNTESIS COLABORATIVA A TRAVÉS DE CONTEXTOS REGIONALES DIVERSOS

\section{Resumen}

Este artículo ofrece un conjunto de ilustraciones o historias únicas que intentan demostrar ejemplos de enfoques críticos de la educación ambiental (EA) en diversos contextos. Se basa en las experiencias de cinco educadores ambientales, en cuatro regiones diferentes del mundo. Detallamos la historia del surgimiento de la conciencia crítica en la educación, en Brasil, y su aplicación en este país. Luego, pasamos a ejemplos de respuestas críticas referentes a la opresión en Nueva Zelanda y Zimbabwe, antes de cerrar con un examen crítico de la enseñanza e investigación innovadoras en Europa. A través de esta amplitud de esfuerzos, identificamos puntos comunes en todos estos contextos, como la importancia de la acción participativa y de la investigación para examinar las relaciones entre las personas y el medio ambiente, en particular como constituido por pueblos indígenas, y para interpretar las realidades de forma a capacitar, a través de sistemas sociales y ecológicos orientados al aprendizaje, un cambio

\footnotetext{
${ }^{1} \mathrm{PhD}$, Senior lecturer, Faculty of Education, University of Waikato, New Zealand. c.eames@ waikato.ac.nz

${ }^{2} \mathrm{PhD}$, Senior Lecturer, Department of Environmental and Life Sciences, Karlstad University, Sweden. per.sund@kau.se

${ }^{3} \mathrm{PhD}$, Senior Researcher, National Institute for Research in Amazon, Brazil. higuchi.mig@gmail.com

${ }^{4} \mathrm{PhD}$, Professor, Environmental Sciences Department, Federal University of Sao Carlos, Brazil. haydee.ufscar@gmail.com

${ }^{5} \mathrm{PhD}$, Professor, Environmental Learning Research Centre, Rhodes University, South Africa. r.odonoghue@ru.ac.za
} 
efectivo. Consideramos que este enfoque crítico pueda promover la emancipación del aprendizaje individual y colectivo, en procesos de EA, en contextos muy diferentes.

Palabras clave: Enfoques críticos. Educación ambiental. Contextos diversos.

\section{EXPLORANDO A CONSTITUIÇÃO DE EDUCAÇÃO AMBIENTAL E OS PROCESSOS CRÍTICOS DE APRENDIZAGEM E MUDANÇA: UMA SÍNTESE COLABORATIVA ATRAVÉS DE DIVERSOS CONTEXTOS REGIONAIS}

\section{Resumo}

Este artigo oferece um conjunto de ilustrações ou histórias únicas que remetem a exemplos de abordagens críticas para a educação ambiental (EE) em diversos contextos. Isso decorre das experiências de cinco educadores ambientais, em quatro regiões diferentes do mundo. Abordamos a história do surgimento da consciência crítica na educação, no Brasil, bem como sua aplicação no país. Em seguida, passamos a exemplos de respostas educacionais críticas relativas à opressão na Nova Zelândia e no Zimbabwe e, para finalizar, há uma análise crítica de ensino e pesquisa, tidos como inovadores na Europa. Através desse esforço, identificamos pontos comuns em todos esses contextos, como a importância da ação participativa e da pesquisa para examinar as relações entre as pessoas e o meio ambiente, em particular como constituído por povos indígenas, e para interpretar as realidades de forma a capacitar, através de sistemas sociais e ecológicos orientados para a aprendizagem, uma efetiva mudança. Consideramos que essa abordagem crítica pode promover a emancipação, através da aprendizagem individual e coletiva, em processos de EA em contextos muito diferentes.

Palavras-chave: Abordagens críticas. Educação ambiental. Diversos contextos.

\section{Introduction}

This article draws together five university-based environmental educators from four different countries of the world to engage in the challenge of exploring the constitution of a critical approach in environmental education (EE) research and praxis. As we each shared our stories on the constitution of our critical education projects in our diverse contexts, it became apparent that one could not speak of the constitution of critical approaches in EE except at the abstract level of an academic field of theory that was unevenly distributed and drawn on in diverse and often contested ways.

Rather than hoping to meld such diverse experiences into a communally-written article, we present here a set of five unique vignettes which each describe and reflect on the critical dimension of EE in their context. As a developing field, EE began to proliferate in the 1980s, primarily in response to environmental degradation and social-ecological problems that were developing in different ways across a rapidly globalising world. Processes of EE were responsive and critical in nature and were orientated to undertaking education in ways that might address a widening and deepening set of local and globalising social-ecological problems. Alongside the development of new teaching and learning processes came the imperative to consider both the concerns that were beginning to drive EE and the innovative practices that were being undertaken to engage people in resolving these.

We note then that EE as a field had critical roots in its own right. It had emerged as a field of critical engagement at the nexus of modernity and emerging social-ecological risk, and expanded and diversified with the advent of Critical Theory that drew on ideas of the Frankfurt School, the counter hegemony of Gramsci, and the critical literacy of Freirian emancipation. This latter work of Freire's, for example in Pedagogy of the Oppressed (FREIRE, 1972) 
advocated a dialogical process centred on critical literacy, and this imperative to emancipate was picked up and worked with amongst oppressed peoples in many parts of the world, as it continues to be, where environmental educators focus on critical emancipation in response to social marginalisation and ecological degradation (UNESCO, 2014). Early Critical Theory was successively expanded and re-written in diverse contexts of $\mathrm{EE}$ to variously constitute education as an empowering and transformative process of change. The notions of liberation and emancipation in South America were taken up in wider education arenas as co-engaged, reflexive research for learning-led change. This drew on the action research of Kurt Lewin and the diversifying intellectual narratives after the Frankfurt School as well as a series of rapidly expanding critical discourses that were taken up by Australian researchers such as Huckle (HUCKLE, 1996) and Robottom (ROBOTTOM \& HART, 1993) and have now extended their reach to all forms of oppression and to a concern for the more than human (ABRAM, 1996; HART, 2005), for example. Within this proliferating diversity of critical perspective, the implicit critical disposition of most environmental educators variously expanded and diversified their work to constitute the diverse array of critical practices that are found across the field of EE today.

As we discussed the current characterisation of critical approaches to EE, we found that we each had a shared story of EE as a critical process and that our diverse contexts guided our pedagogical practice and our research. These stories are embedded in the vignettes that follow in two clusters of engagement that examine the critical contours of the situated, co-engaged learning and change in our diverse contexts, firstly through dialogical engagement, and secondly through critical research and teaching.

Our purpose here is to attempt to illustrate how taking a critical approach to EE can inform our thinking in different cultural contexts and the possible consequences for education and research. EE has been argued to be an effective vehicle for social transformation and these vignettes provide examples of successes and challenges for that change. We hope that these vignettes can act as a stimulus for environmental educators' critical reflection, to assist in avoiding making transformational educational projects mere functionalist enactments that centre on awareness creation and model rational scientific thinking towards some desired environmental learning and change. By examining how this might work in diverse country and community contexts, we emphasise $\mathrm{EE}$ as educating from the learners' realities, drawing on intergenerational thinking as well as indigenous traditions of education, and explore then what it might mean to research and teach in a critical way.

\section{Dialogical engagement in country and community contexts}

\section{The emergence of environmental education practices and research as a critical process in Brazil - Haydée Torres de Oliveira}

This vignette offers some thoughts on the emergence of an approach in environmental education (EE) and EE research as a critical process in Brazil: not so much in accordance with theoretical ideas of the Critical Theory tradition, but as the result of critical engagement and critical approaches, including performing ways of becoming critical, and taking into account the context of huge social inequalities under a dictatorial political regime in the country. The roots of EE in Latin America (OLIVEIRA, 2008) derived from the same source as Popular Education (PE), in spite of differences and internal contradictions between them; the stable that nurtured, during the 1960s and 1970s, groups who aimed to reorganize social movements in Brazil and channeled the desire for democratic freedom and social justice; in other words, the desire for social transformation. The branch of EE that has been called transformative EE started to grow during the 1980s, when people involved in PE got together with activists from 
social movements, especially environmentalists whose activity was aimed at social transformation and the radical questioning of the industrial and consumerist way of life under neoliberalism/capitalism. The environmental movement also overlapped with the workers' and students' movement, especially at universities (OLIVEIRA, 2004).

Several key events mark those years around the birth of EE, such as the foundation of CEPIS - Center for Popular Education of the Institute Sedes Sapientiae (1978), PT - Workers Party (1981) and CUT - United Trade Union Congress (1983), among others. At the same time, in the educational field, according to Puiggrós (1994), the emancipatory perspective of education owes much to the Brazilian thinker and educator, Paulo Freire:

By postulating a dialogical relationship and burying the reproductionist theories, Freire provided elements that allow us to study in the pedagogic subject the symbolic expressions of the different relative positions of the educator and the learner and their consequences for the production, reproduction and/or the transformation of culture. This was probably the most important discovery in Latin-American popular educational thought in the second half of the twentieth century (p. 4).

In the Latin-American Guide to Environmental Education, we can find the expression Environmental Popular Education (Viezzer \& Ovalles, 1995), referring to the EE program of the Adult Education Council for Latin America (CEAAL), jointly responsible for publishing this guide with the Network for Environmental Training in Latin America, a part of the United Nations Environment Program (UNEP), Rede Mulher and the Ecoar Institute for Citizenship. Even though the word 'environmental' in Popular Education or the word 'popular' in EE had not taken root to that point, the perspective taken in the Guide was one of promoting transformation, not only in the socio-environmental conditions, but also in the learning systems and paradigms of knowledge. The close association between the proposal and development of participatory approaches to social and environmental education research within PE and EE was also taken up by Brazilian educators and researchers.

One example of considering socio-environmental conditions is through environmental justice. Acselrad (2005) discusses the historical origins of the concept of environmental justice in the 1960s in the United States, in the bosom of the civil rights movements of Afro-Americans, who were the most exposed to environmental risks in that context. In the Brazilian context, Acselrad includes mention of the movements of those affected by dams, rubber-planters, babassu palm-nut breakers, among other movements of great political potential, in a country marked by profound inequalities in income distribution and access to natural resources. Bullard (2004) has called these injustices environmental racism and defined this as a form of institutionalized discrimination, reflecting actions or practices carried out by members of dominant racial or ethnic groups, which have distinct and negative socio-environmental impacts on members of (racial or ethnic) subordinate groups. These actions can include economic exploitation, racial oppression, devaluation of human life and the natural environment and entrepreneurial greed. In all these struggles, the perspective of citizenship is, obviously, present and this is another focus shared between the EE and PE movements.

There is a recognition, to some extent, that the experience with EE in (non-formal) community education was richer in Latin America than in some European countries, like Spain, for example, where EE was spread more within formal teaching systems (GARCIA-GÓMEZ, 2000; GONZÁLEZ-GAUDIANO, 2007). According to the latter author, this implies that EE in Latin America has been aimed more at the adult population than at schoolchildren, and is more present in rural than in urban areas, though to a lesser extent in Brazil owing to the intense urbanization over the last three or four decades; and also that greater emphasis has been placed 
on projects of social and community development than in the developed countries, where conservationist and scientific approaches are more entrenched.

From a theoretical and methodological viewpoint, dialogical and participatory approaches for action and research have been incorporated more and more in the repertoire of environmental educators in Brazil, since it opens up the possibility of seeking coherence and epistemological vigilance with the presuppositions of a critical and transformative EE. Thiollent (1986), Brandão (2005a, 2005b) and Viezzer (2005), pre-eminent workers in this field, together with Paulo Freire over an extended period of time (FREIRE, 1985, 2007, 2013), created emancipatory perspectives that can be seen as important in setting up the field of EE in Brazil. It is also worth emphasizing the role that a transdisciplinary approach has in EE, since the dialogue between different forms of knowledge emerges strongly in the field of non-formal education, as other learning systems are also present, and could and should be placed on the agenda of EE (OLIVEIRA, 2005a, 2005b), linked to what Wals and collaborators described as social learning (WALS, 2007).

The search for new paradigms brought together some elements that broadly coincide with those we have been considering in EE, namely: a) the view of the educator put forward by Carvalho (2004), as an interpreter of her/his reality seems to afford an adequate perspective from which to think of a critical EE, as it emphasizes that we can always rethink, reinterpret what we see and do and what affects us, in the light of new considerations, of a dialogue with our interlocutors, of new perceptions and feelings and of the experiences accumulated throughout our lives. In other words: the re-signification of the life-world; b) the retrieval of the memory, the imaginary, the perceptions that form the basis of world visions are also valued elements in both EE and PE and deeply informed by the cultural diversity in the country; c) context-based, cross-sectional and interdisciplinary - one of the key points of Freire's pedagogy is to educate from the learner's reality, which is also a fundamental presupposition of EE worldwide; d) an EE process that recognizes the interdependence of the economic, political and environmental dimensions; that clearly enunciates ethical and esthetic values and the need for EE to involve the whole of the formal teaching system and all other educational settings.

At the international level, we find that the Latin American experience of developing EE with a critical lens hasn't had the opportunity to become widely known, despite the efforts of UNESCO in proposing a Decade (2005-2015) of Education for Sustainable Development, as pointed out by González-Gaudiano (2003). In this way, this vignette makes a small contribution to overcoming the linguistic barrier that prevents the dissemination of Brazilian EE experiences. Iared et al. (2015) pointed out some ideas about these questions of language, discourse, interpretation, meaning, description, explanation and representation, issues that must be taken critically and reflexively. The next vignette takes this dissemination further by exploring how such a critical approach occurred in the Brazilian context.

\section{Community integration: a process for a critical socio-environmental change - Maria Inês Gasparetto Higuchi}

The participatory action research proposal (PAR), suggested by López-Cabana and Chacón (2003), is "a peculiar model of action research that is characterized by a set of principles, norms and methodological procedures which provides collective knowledge to transform a given social reality" (p.170). In this research model, the paths are often set reciprocally, by the researcher and the researched, and thus produce results that are not necessarily grouped as purely research or as activities per se, since both belong to the same social reality (LOUREIRO, 2010). An example of this process provoked an interesting partnership between people of an urban community and a research institution towards preservation of a native forest in Manaus-Amazonas State, Brazil. 
In the 1990's, when Manaus faced many problems of habitation, people started to invade the campus of the National Institute of Research for the Amazon (INPA - a federal institution focussed on environmental research) located in the urban perimeter of the city. INPA used that native forest area as a laboratory for postgraduate students to study the forest ecosystem, its ecological dynamics and its biodiversity. The forest area ( $15 \mathrm{ha}$ ) began to be invaded by people looking for a place to live, or for those who already lived nearby, as a place to have their extended families living close. The community and INPA struggled over that piece of land for months, each fuelled by a different justification: the institution considered the land as an important and necessary natural reserve for the city and for their studies, while the neighbouring residents considered it land without social meaning.

INPA's researchers emphasised the importance of protecting the natural vegetation and animals in the area, but the residents were destroying the institution walls, chopping down the vegetation and killing the animals for their needs. INPA's aim was to show the significance of, and necessity for preserving natural resources, for what ecologists would call a 'better quality of life'. The resident people wanted to clear that area for a place to live.

The Department of Environmental Education of INPA was asked by the Institute Director to "solve that problem". The approach taken to address the problem was to firstly understand what people were trying to say through their 'destructive' practices. In a meeting between the educators and the invading residents, the residents' expressed needs were, at first glance, quite simple: have an educative place and job opportunities for their children and youth, who did not have anything to do, so were living in the streets where they were vulnerable to the drug dealers and other types of urban violence. However, how could environmental educators meet these people's request effectively? And to what extent might we risk imposing a new set of behaviours by virtue of the obvious power the Institute represented against those who, by comparison, have little or no political power?

As an institution, INPA had, then, to rethink the use of that piece of land to give it significant social relevance for those people. An idea of turning the area to a visiting park came about during the meetings among the researchers and the community. After much discussion, INPA's staff agreed to have part of the main campus transformed into a park called Science Grove. A programme 'INPA \& Society' was launched through the project named Young Guides of the Science Grove, integrating children and adolescents in an environmental education process. The insertion of the community youth in the INPA's enterprise was based on the premises of Freire's (1983) postulations and the theoretical assumptions of EE that the environment does not exist independently of people's social relations, and that the formation of an environment implicates at once the formation of the person (PROSHANSKY;FABIAN;KAMINOFF, 1983; KORPELA, 1989; GARCIA-MIRA, 1997; FISHER, s.d.).

From the beginning of the project, participatory action research was conducted, in the belief that $\mathrm{EE}$ is not only education in favor of the environment, but rather it should be education directed at people in the transformation of society (SUAREZ; MARCOTE, 2009), to include a change of values and social standards for full citizenship (LOUREIRO, 2003; GUIMARÃES, 2007; REIGOTA, 2008). This transformation should reach not just the immediate relationship of people with their surroundings (the natural environment which should be preserved), but requires changes in many other social dimensions to allow new ways of doing things, and a new ethic that implies an improvement of social relations, considering all beings and things that are around us (LOUREIRO, 2004a 2004b; 2010; GUIMARÃES, 2004a; 2004b; CARVALHO, 2008; GONZALES-GAUDIANO; LORENZETTI; 2009; LAYRARGUES, 2010).

By understanding, therefore, EE as a social transformation platform, enables us to work with people and produce knowledge about people-environment relations. Thus, the territories are extended and the social relationships diversified to reflect the way life is (HIGUCHI; 
MAROTI, 2014). The green area that was a natural laboratory became a zoo-botanical garden and the adolescents became a part of the place. INPA's project thus offered a place of education, but could not give a job in the way the residents were initially requesting, although this did not become a problem.

The adolescents entered into a long-lasting program with three phases, starting with one year of critical formation (weekly meetings with researchers, visiting places where they dreamed to go but could not afford; environmental care practices and psychosocial development activities - identity; self-esteem; cooperation; communication abilities; friendship). All these experiences happened within a discussion of moral values, social equality, social rights and responsibilities within a democratic society and so on.

Following this first phase, the adolescents went on to a more active phase: the guiding activity of the Science Grove's visitors, which enhanced their personal communication skills by presenting the place and some simple explanations of the ecosystem to visitors for one year and 6 months. The objective was to enable them to attain a citizenship and improvement of their self-esteem by providing them a social visibility of their own capacities. After this, the adolescents engaged in other projects called large community with the goal of empowering children's actions in their neighborhood, encouraging group initiatives, and providing opportunities for their capacities. The project gained great visibility in the city and in other regions in Brazil. The program lasted for 15 years and was attended by more than a thousand adolescents from the communities around INPA.

Evidence of change could be seen as the INPA's walls were let untouched; the invasion of the area by people stopped and the animals that escaped were carefully taken back to their habitat; families started visiting the park; the adolescents brought their own schools to the park, and drew on the help of the INPA researchers in their school work, either by inviting them to give a talk at their school or by visiting them in their laboratories to understand what is science about. Such transformations were motives to celebrate the attainment of the goal of effective community integration for a critical socio-environmental change (LAYRARGUES, 2010).

In this project, the EE goal was not to give scientific information on the ecosystem, or putting together a list of environmentally friendly behaviour. On the contrary, it intended to help these people to think about the reality in which they were engaged and how they might transform it, so that it could be beneficial for them and for other people and for the environment. More generally, it became critical of the prevailing orientation of the majority of environmental education programmes which were trying to advocate for all a 'better life' or 'viable future', in Milton's terms (1993, p. 2), without realising that the objectives were some distance away from the interests and values of the people.

Much of this conflict between people and the environment can be attenuated if we consider some theoretical questions. By advocating an undifferentiated responsibility towards 'the environment', those who endorse normative strategies fail to apprehend the multiplicity and the complex nature of the phenomenon. For, in Milton's words, "there are many visions of a viable future, and diverse answers to the question for whom, or what, it should be viable" (MILTON, 1993, p. 3). In fact, a number of studies have shown that the significance attributed to the environment is socio-culturally determined (see for example, BUTTS, 1989; VAN BEEK; BANGA, 1992; BLOCH, 1995; DESCOLA; PÁLSSON, 1996).

Given that people actively constitute the ideas of the environment in whose terms they interpret and act, and that this occurs in a continuous and dynamic process that implies for each one of us a particular history of inter-subjective relations with others, understanding this cognitive process of continuity and transformation can contribute to finding reasonable answers for the contemporary ecological quandary. This being so, it seems that a good starting point would be to uncover the significance of this concept that people hold dear and express in terms of social practices: changing people's lives is changing the environment in which they are 
engaged. The community integration in the Science Grove resulted in more than awareness of the natural environment, as one of the adolescents said: "being part of this space was the chance to be happy, to care about the trees, animals and, much more, knowing and respecting different people".

This vignette has described a project which took a critical approach towards engaging in socio-environmental change in a Brazilian community. Our next vignette explores how a similar approach is and could be employed for a project in a community in Aotearoa New Zealand.

\section{Community partnership for urban ecological restoration - Chris Eames}

This story is about the development of a community partnership environmental education (EE) project in Taupō, a small city in the Central North Island region of New Zealand. The city lies on the shores of a large lake, revered for its clean waters and abundant fish, and its majestic vistas across to a group of volcanoes. The city is economically focussed on tourism, drawing on water sports, fishing and aesthetics for its appeal. Until around 160 years ago, the region was completely clothed in native forest and grasslands and supported a strong tribe of indigenous Māori people, the Ngati Tūwharetoa (COOPER, 1989; GRACE, 1959). Colonisation by European settlers from the mid 1800's led to subjugation and eventual largescale displacement of these indigenous people and clearing of their lands, culminating in a predominance of agricultural and exotic forestry land-use today. The consequent ecosystem changes have resulted in significant loss of biodiversity, agricultural pollution threats to the habitat and amenities of the lake, and a community desire for reconnection of the city to the natural environment.

These imperatives have spawned a community partnership EE project called Kids Greening Taupō. This partnership is bringing together an environmental non-government organisation (Greening Taupō), a government department charged with conserving natural and built heritage (the Department of Conservation [DOC]), three schools and two early childhood centres, Ngati Tuwharetoa tribespeople and Taupō District Council. The focus of the partnership is to restore the urban environment through environmental education.

Restoration is by definition a critical project. It involves an examination of what used to be, a critique of how changes brought about the current undesirable state, and a vision for how a more desirable can be achieved. Critical education can play a part in each of these phases. With the range of ages of the school students involved in this project being from 3 to 18 years, and beyond that into the wider adult community, this necessitates some careful educational design.

In examining the environment as it used to be in the Taupo region, the students seek historical records through inquiry processes. They draw on artefacts from libraries and museums and probe for information from local scientists and historians. They connect conceptual knowledge of ecosystems and biodiversity with an understanding of place, visualised through old photographs and descriptions. Ngati Tuwharetoa, like all Maori, had an oral tradition of passing on information (GRACE, 1959), and their storytelling becomes important here in evoking a sense of loss and a consideration of values for what has been lost. Philosophies that still guide Maori in their interactions with the natural world such as kaitiakitanga (a guardianship role for nature), whakapapa (that we are all related to everything living and non-living), and mauri (the spirit within everything) underpin this values exploration (TE ARA, 2015). Experiential learning becomes important here as students visit isolated remnants of the formerly dominant ecosystems and contrast those with the modified spaces that currently exist within the city. Students develop a sense of being that can guide their thinking (FROMM, 1976). 
Critiquing how changes led to an apparent need for restoration also draws on historical understandings that highlight the complexity of the interactions between the social (cultural, economic, political) and the environmental. The nature of the critique must vary with the different age groups of students, becoming more sophisticated as the students get older and more capable of critical reflection beyond the self (PIAGET, 1954). This phase is handled sensitively as clearly students are not agents in these changes, merely the inheritors of the consequences (JENSEN; SCHNACK, 1997). To develop an understanding of the imperatives that drove the changes requires students to cast themselves back in time to situate their thinking as someone of that era.

Māori began the transformation of the original ecosystems as they settled in the area from around the 1400's. Beginning in small numbers, their hunter-gatherer existence would have had little long-term impact on the environment. As their population grew, a more agrarian lifestyle developed with larger settlements drawing more resources from the forests and waters, but still the impact was small. Their focus was on sustaining their lives and their economy was localised. The arrival of European settlers brought about significant change. These settlers brought tools that could create faster and wider impacts on the land (axes, saws, horses and later steam power) (COOPER, 1989; GRACE, 1959). More importantly, their economy was much less localised, with imperatives to create farms that could supply growing towns within New Zealand and markets in the United Kingdom. This led to widespread land clearance and habitat loss but also encouraged development of an urban centre that became Taupō (COOPER, 1989). This centre developed a society that enhanced the wellbeing of the settlers and it can be argued, the local Ngati Tuwharetoa people, through health, education, housing and commerce developments. The farming that surrounded the new town also contributed to the broader New Zealand economy leading to its position today as 'developed' nation.

Understanding and critiquing these changes leads to pedagogical strategies such as role plays where students can 're-live' the conditions of those times. Development of political literacy at this point would help students gauge the processes of decision-making that may have brought about these changes and to weigh up the advantages and disadvantages that those changes have wrought upon their current situation. This would help them to critique rather than merely criticise their forebears, and permit a clearer vision for things could be.

The final phase of creating and enacting that vision is the ultimate goal of restoration, but one that should be underpinned by the first two phases. Without that underpinning, the restoration process may be, and the associated education will be, less effective than it could be. Envisioning restoration begins then by critiquing the current situation and what changes would be desirable. This again involves values exploration by considering and consulting those in the environment, both human and non-human. It requires examination of the underlying causes of any environmental and sustainability issues in the situation and an investigation of possible solutions. Collaborations can then be built to address the issues through viable solutions. The students must be empowered through enabling their active participation in decision-making in order to gain the educational outcomes that are possible.

In the Kids Greening Taupo project to date, the partnership has worked together to broadly scope the first two phases of restoration. They have drawn on Ngati Tuwharetoa and local scientists to provide historical information. Whilst these sources have sought to bring a critical/historical perspective to the project, it is unclear yet whether this is becoming apparent in the education settings. Rather, these partners appear to be more focussed on the third phase, that of physical restoration, perhaps sensing that doing something is a more important output than researching and planning for engagement of students early on. This emphasis on ensuring that quick restoration progress is explicitly apparent and visible has been observed elsewhere in environmental education projects (EAMES; ROBERTS; COOPER; HIPKINS, 2010), and the need to move beyond this early stage to critical reflection and deepening practice is crucial 
as this project develops. This deepening holds potential to fully realise the twin objectives of restoration and education in this project.

These first three vignettes have explored the ways that critical approaches to EE have emerged and been applied in different contexts, both at a country and community level. This practice is addressing issues of socio-ecological change, cultural and political injustices and creating hope that humans and non-humans can flourish together in a sustainable world. We now turn our attention to how critical approaches to EE have been manifest in research and teaching in two further contexts.

\section{Critical Research and innovative Teaching}

\section{Contemplating African heritage in ESD as critical processes of situated learning-led-change - Rob O'Donoghue}

A small fragment of the earlier Miombo woodlands of Harare, Zimbabwe, today is now a wildlife park containing eland, a large cattle-like herbivore of the African woodland, amongst other ungulates and a wide variety of birds. These fascinate tourists, who take photographs of them in a spring-fed wetland, now waterhole. The open grassland that reaches into shaded woodland masquerades as African savanna wilderness, but this is actually a remnant of the social-ecological commons of the Shona, a fire-modified ecosystem of grasses and trees where people thrived with their cattle and where perennial streams watered wildlife, livestock and homestead food gardens.

Today, despite the drought of an El Nino year intensified by regional climate change, the water is still plentiful, although the wetland no longer extends into what are now the eastern suburbs of the modern city of Harare. The Shona, like indigenous peoples all over the world, are now part of a modern cosmopolitan state in need of education for sustainable development (ESD) for learning-led change towards a more sustainable future.

Read in simplifying overview, it is possible to track how the transformation of The Commons and changing education practices have always been 'behind the times to come;' in this case, a modern era of risk where there is now a need for ESD to foster learning and change. The educational change is currently playing out in social imaginaries for producing sustainable futures. Over times of past change, education, not unlike ESD today, has developed as similarly abstracted propositions to be enacted as 'salvation narratives' for producing a desirable future. The colonial past of education reflects an exploitative paternalism initially to save the native with Western forms of literacy and to privatise the commons so that it became the productive resources of citizens and corporate business in a modern capitalist economy. In southern Africa, this developed within a fascination with wildlife and ecological sciences that cast the ignorance of the native as the threat to the biodiversity in wildlife parks.

In response to emerging risk created through the last century of rapid social-ecological change, and not unlike in the recent past when conservation and environmental education were advocated, ESD has now emerged as a social imaginary for enabling necessary learning-led change towards a sustainable future. In most cases, however, the envisaged educational practices for enacting the desired future have been centred on awareness creation and models of process for the rational mediating of the desired environmental learning and change. It is becoming apparent that by approaching education in this way, the educational practices for getting to a desirable end have been surprisingly elusive. 
Over the past decade or so, ESD has emerged as a concept to foster transformative social learning in curriculum settings and expanding education activities to conserve biodiversity. The past United Nations Decade of Education for Sustainable Development has served both to shape and to clarify ESD as a proposition for implementation in five priority areas through a Global Action Programme towards transformative learning for future sustainability (UNESCO, 2016). Against the prioritising of biodiversity conservation in many African ESD programmes, the question that this vignette explores is how has the enactment of these modern education imperatives in African contexts developed as somewhat blind processes that are not yet realising more sustainable livelihoods and landscapes within which biodiversity is assured. ESD as learning-led social-ecological change is an alternative to change as an arbitrary outcome of escalating social, economic and political conflict or natural disasters that have characterized change in earlier times. However, where the referent has been a colonial ideal of wild nature over a livelihood producing social-ecological landscapes, the enactment of ESD for conserving ecological biodiversity merits careful review, so that it might be coherently situated and realised through quality education practices that play out in ways that are relevant in emerging African contexts of modernity.

The search for an alternative to a functionalist enactment of pedagogical transformation for enabling students to give effect to change is not an easy matter and yet there is emerging evidence of how, working within African philosophical perspectives, students on the margins of modernity in southern Africa have been able to thrive in ways that have enabled them to be successful in modern schooling.

Madzima (2010) describes how, in conditions of poverty and socio-economic collapse, a group of young learners from marginalized communities were successful at school where others failed. She probes how their success was achieved through a sustained and collaborative effort where they drew on cultural resources to transcend the innumerable barriers that they faced in daily life and in a schooling system that brought numerous other literacy, learning and assessment task challenges. She writes:

It was found that they drew strongly on Shona Hunhu cultural resources. These enabled them to become successful despite the daunting conditions in which they found themselves (MADZIMA, 2012).

In this way, drawing on the cultural resources of the Hunhu philosophy, the learners constituted realities that enabled them to be successful "through their own local truths and worldviews" (MADZIMA, 2012, p. 22) that she notes had hitherto been silenced, excluded or remained unrecognised within a dominant 'Western Canon' and its education system.

In another study on relations between home and school where the African philosophy of Ubuntu was an important process of solidarity and collaborative endeavour, Maqwelane (2011) found that the inclusion of indigenous knowledge practices in interactions with grandmothers (Gogos) enhanced literacy and learning in Foundation Phase learners. Her focus was on intergenerational, healthy living practices that she worked with in collaboration with grandmothers on literacy skills in the life skills curriculum. This served to contextualise the curriculum content in ways that the students had a relevant foundation for learning to read and write as well as address health issues by exemplifying their heritage knowledge practices.

Both cases of the enactment of a situated cultural philosophy of self-reliance and solidarity for the common good reflect situated agency through a collaborative engagement that draws on cultural resources to foster success in schooling. This suggests that heritage resources might be important for well constituted models of process like ESD to be brought into useful effect as a foundation for learning to thrive and transcend social-historical processes of marginalisation. 
Hunhu-Ubuntu (SAMKANGE, 1980), that was framed in the social-ecological context of the Miombo woodland landscape, provides a situated capital of commons and community propositions for enacting ESD as a reflexive model of process for expansive learning. It provides the situated cultural capital for framing ESD within our transformed commons as emergent socio-cultural process theory for narrating learning and change. Here the concern shifts from wildlife and biodiversity to a biodiverse socio-ecological landscape and sustainable livelihood practices. History and deliberative ethics provides a necessary capital for reflexive learning for enabling learners to draw on a capital of cultural dispositions and life experiences to raise questions and take up critical vantage points for a dialogical engagement with issues and risk. In this way, participants in ESD might be better able to situate, contemplate and model The Commons, change over time for the common good.

This vignette has examined how traditions from diverse contexts have been disrupted through a critical approach which indicated how education can be perceived in different ways within an African context. Our final vignette takes us to Europe for a critical analysis of how EE research is informing practice.

\section{The rope of practice and traditions: Continuity and critical change - Per Sund}

This vignette discusses how ideas that were initially developed within Critical Theory can be applied to educational development within the environmental and sustainability education (ESE) research field. It considers what characterises 'good' environmental and sustainability education research (ESER), how this can be critically discussed, and what the relation is between the research, practice and educational philosophy.

My experiences as a convenor for the international environmental and sustainability education network, ESER, as reviewer of conference presentation abstracts to the annual European Conference on Educational Research, ECER, and as a participant in numerous research conferences, have led me to critically think about what counts as 'research'. Many practitioners at these conferences claim to set out to demonstrate new innovative practices and effective teaching methods, yet these often appear to be traditional educational experiments. Issues related to content, attitudes and long-term aims dominate in these conference presentations, while complex learning processes are often taken for granted.

The problem with these presentations is not the innovative aspect itself, but that the teaching innovations are trialled over short periods and show little connection to the thinking and knowledge traditions that have lasted for hundreds of years. One way of making these innovative educational development ideas become part of 'the research' is to deliberately tie them to the thinking traditions in educational philosophy and the knowledge traditions in the specific research field.

Educational development 'research' with no connection to educational philosophy and the research traditions of ESE can result in normative prescriptive statements about which 'right values and best actions' should be stressed in ESE, that may essentially be regarded as miseducative (JICKLING; WALS, 2008). Change for the better, whatever this might mean, might be a noble cause, but should not tempt researchers and educators to force distinct solutions and behaviour change strategies onto students and members of the public. Arendt (1961) raises the crucial point that any political use of education and any attempt to produce the new as a fait accompli (p. 176) can only be regarded as indoctrination. A lesson that can be learned from these ideas is that we should avoid pushing a normative agenda in education and educational research. Instead, as Arendt (1961) suggests, the educational situation is a space for explorative actions. If the purpose of the teaching is to promote specific societal development, then the educational intentions ought to predict what a future society will be like. However, as no-one knows what the future will bring, democratic considerations and critical questions, such as 
whose ideas are most fruitful, why they are worth considering and in whose interests, remain central in education and ESE research.

The type of authoritarian and normative teaching development, which is often presented as 'research' at conferences, can be avoided by tying practice to thinking and knowledge traditions (see Figure 1). The importance of a critically informed and action competent public is still central in ESE. Why then are centuries of work within the field of educational philosophy so often ignored in the research field?

Thinking traditions in the philosophy of education (collective) include: behaviorism, constructivism, sociocultural, pragmatism, modernismpost modernism, structural-post structural, realism etc

Teaching subject/area (individual) social, economy, ecology

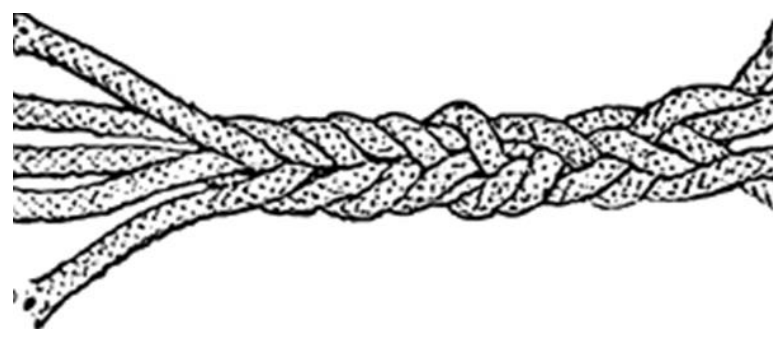

Knowledge traditions (collective)

disciplinary traditions

contextualisation in the research field

\section{Figure 1. A rope metaphor - making research critical and cumulative}

The interplay between individual teaching habits and collective traditions (for example, institutionalised disciplinary traditions) seems to aptly describe how teaching development in ESE evolves and is consolidated in the formal school system (DEWEY, 1922). This means that what a practitioner at a conference claims to be innovative teaching is often part of a longer history of 'traditions' that have evolved during decades of ESE teaching. Teaching is something that is continuously developed as a result of encounters between earlier and current experiences. Individuals develop their teaching innovations on the basis of the contextual situations that have been created by earlier generations of teachers and disciplinary traditions. As an individual does not live in a vacuum (DEWEY, 1938/1997), being innovative is not always easy, although at the same time this cumulative fact makes it easier for empirical innovations to be part of the bigger picture of practice, thinking and knowledge traditions.

Figure 1 shows that there is a mutual dependency between educational philosophy, research and practice: non-contextualised and non-theoretical 'innovative research' will not have any long-term effects on practice or research or affect the evolution of educational philosophy. Likewise, research and educational philosophy that are completely unconnected to practice (unempirical) will not have any long-term effects on research, philosophy or practice. 
This claim may be regarded as controversial, in that some philosophers, e.g. Wittgenstein (1953/1992), are critical of building firmer theoretical structures of reality, whereas other educational philosophers, such as Dewey and Bentley (1949/1991), encourage educational research to use empirical methods and try and test philosophical theories in a teaching practice that is informed by scientific enquiry.

The rope metaphor shows that innovative educational development, which risks becoming a solitary soap bubble floating in the air at a conference before vanishing from history, can empirically affect educational philosophy and contribute to the development of the research field if the presentation is well contextualised in the research field and grounded in educational philosophy. In the rope, these three areas can continuously strengthen each other and become part of a long common history. However, at the same time, innovative ideas could become part of future cumulative, known and documented knowledge. Innovative educational development can make a difference by:

Inspiring theoretical and philosophical progress

Ensuring long-term practical input

Contributing to the research field

Without contextualisation and explicit links to centuries of relevant educational theories, research presentations of innovative educational development at conferences risk appearing disconnected from teaching development or having little inspirational effect on research and educational philosophy. While the ESER rope needs new innovative stories, they need to be critically examined in terms of what is 'new' about them.

\section{Synthesis and conclusion}

This presentation of five vignettes has illustrated for us the constitution of EE as situated, critical processes of learning and change. We recognise that critical perspectives in EE draw not only, and not always, from Critical Theory, but also take a broad view of being critical in examining assumptions, traditions and impositions in seeking social transformation. This opens up dialogues about participatory action and research that goes beyond a normative approach to education to examine people-environment relations, particularly as constituted by indigenous peoples, and to interpret realities that may differ from a hegemonic (often colonial) viewpoint. This interpretation was clear in the struggles between the community and the INPA in Brazil, in the re-conceptualisation of an urban ecosystem in New Zealand, and in the lands of the Shona in Zimbabwe. These provide alternative explanations for social-environment relations that can help us to view the world in different ways.

These relations question the imposition through EE of behaviour change strategies that disenfranchise the people, and point more to emancipation that facilitates empowerment of local people to find their own local solutions to environmental and sustainability issues. The goals in $\mathrm{EE}$ are then not simply to gain information, alter attitudes, nor even to doing something for the environment, but to create a milieu within which a learner can be empowered through learningled social-ecological change. At present a discourse of targets, efficiency and educational effectiveness, rather than purpose or values, dominates the educational system of many western 
countries (HARTAS, 2010). From a critical perspective, pluralism and reflexivity are crucial elements for a social inquiry with emancipatory potential (SUND \& WICKMAN, 2011), that rejects telling informed citizens what to do with their acquired knowledge normativity and prescription.

Finding local solutions is important when there is conflict of social-ecological relations (LUNDEGARD \& WICKMAN, 2007). These conflicts have been exemplified in this paper between academic research or preservation of wildlife and local peoples' livelihood, and by restoration of an urban ecosystem despoiled by years of exploitation. Often in addressing these conflicts a common pitfall is to approach the solution through education in a too simplistic way, imagining that there is one good solution. The vignettes attempt to show that this type of prescription is not bringing about social transformations that aim to be long lasting. Educational projects need to embrace the diversity of interests of people living in the local and indigenous cultures. Cultural knowledge and resources are valuable assets in these projects.

These vignettes show that cultural resources can be interpreted in different ways, such as local indigenous culture, or culture of research. The final vignette addresses this latter concern for a critical perspective of researchers' claims, of for example research in transformational teaching, that may draw on different cultural contexts. This focus of this vignette could be criticized for keeping a hold on the western research traditions which tend to exclude cultures based in developing and indigenous knowledge. Confronting the dominant perspectives in EE research to include indigenous and post-colonial ways of thinking is a critical approach (ANDREOTTI, 2011).

For environmental educators, this emphasizes the significance of the diversity within contexts for the interpretation of a critical perspective to EE. This significance extends even to the prevailing term used to describe this area of endeavour, whether it be EE, ESD or ESE, all used within the different contexts in this paper. What this helps to explore in a wider sense is the importance of language as, on the one hand, a key element of cultural expression, as explained by O'Donoghue in Zimbabwe, and on the other hand a barrier to learning about issues and responses to them in non-English speaking countries like Brazil, when so much knowledge publication occurs in English (a case in point being this article!).

These vignettes show that a critical approach, in combination with attention to cultural, indigenous and language factors, can foster emancipation for individual and collective learning in very different contexts. Our argument aligns with Sumner's (2008) claim that there does not need to be a conflict between the learning of the individual and the learning desires of society, a debate which has been prominent in ESD research for many years. Emancipated individuals can work for collective benefits. All these vignettes put individual participants in the role of active agents in knowledge production for their own development and for that of society.

\section{References}

ABRAM, D. The spell of the sensuous: Perception and language in a more than human world. New York: Pantheon, 1996.

ACSELRAD, H. Justiça ambiental: narrativas de resistência ao risco social ampliado. In: FERRARO JUNIOR, L.A. (org.) Encontros e Caminhos: formação de educadoras/es ambientais e coletivos educadores. Brasília: Departamento de Educação Ambiental/Ministério do Meio Ambiente. 2005. pp. 217-228.

ANDREOTTI, V. Actionable Postcolonial Theory in Education. New York: Palgrave Macmillan, 2011.

ARENDT, H. Between Past and Future. Six Exercises on Political Thought. New York: The Viking Press, 1961. 
BLOCH, M. People into Places: Zafimaniry Concepts of Clarity. In E. HIRSH AND M. O'HANLON (eds.) The Anthropology of Landscape. Oxford: Clarendon Press, 1995.

BULLARD, R. Enfrentando o racismo ambiental no século XXI. In: ACSELRAD, H.; HERCULANO, S.; PÁDUA, J.A. Justiça ambiental e cidadania. Rio de Janeiro: RELUME DUMARÁ: Fundação Ford, 2004. pp. 41-68.

BUTTS, Y. The People of Amazonia. In Y. BUTTS AND D.J. BOGUE (eds.) International Amazonia: its Human Side. Chicago: Social Development Center, 1989.

BRANDÃO, C.R. Pesquisa Participante. In: FERRARO JUNIOR, L.A. (org.) Encontros e Caminhos: formação de educadoras/es ambientais e coletivos educadores. Brasília: Departamento de Educação Ambiental/Ministério do Meio Ambiente. 2005a. pp. 255-266.

As flores de abril: movimentos sociais e educação ambiental. Campinas: Autores Associados. 2005b. (Coleção Educação Contemporânea).

CARVALHO, I.C.M. Educação Ambiental: a formação do sujeito ecológico. São Paulo: Cortez, 2004. Educação ambiental: a formação do sujeito ecológico. São Paulo: Cortez, 2008.

COOPER, B. The remotest interior: A history of Taupo. Tauranga, New Zealand: Moana Press, 1989.

DESCOLA, P.; PÁLSSON G. Introduction. In P. DESCOLA AND G. PÁLSSON (eds.) Nature and Society, Anthropological perspectives. London: Routledge, 1996.

DEWEY, J. Human Nature and Conduct: an Introduction to Social Psychology. New York: Holt, 1922. Experience and Education. New York: Touchstone, Simon and Schuster, 1938/1997.

DEWEY, J.;BENTLEY, A. F. Knowing and the known. Westport, Connecticut: Greenwood Press, 1949/1991.

EAMES, C.; ROBERTS, J.; COOPER, G.; HIPKINS, R. Education for sustainability in New Zealand schools: An evaluation of three professional development programmes, 2010. Retrieved 5 March 2011, from http://www.educationcounts.govt.nz/publications/schooling/82841

FISCHER, G. Psicologia Social do Ambiente. Lisboa: Instituto Piaget, (s.d.).

FREIRE, P. Pedagogy of the Oppressed. NY: Bloomsbury Academic, 1970/2012. Pedagogia do Oprimido. 13ª . Ed. Rio de Janeiro: Paz \& Terra, 1983.

$\overline{1985 .}$ The politics of education: culture power and liberation. Bergin \& Garvey Publishers, Pedagogy of hope. NY: Bloomsbury Academic, 1992/2013. Pedagogy of the heart. NY: Continuum, 1997/2007.

FROMM, E. To have or to be? New York: Harper \& Row, 1976.

GARCIA-GÓMEZ, J. Modelo, realidad y posibilidades de la transversalidad: el caso de Valencia, España. Tópicos en Educación Ambiental, vol. 2, n. 6, pp. 54-62. 2000.

GARCIA-MIRA, R. La ciudad percebida: uma psicologia ambiental de los barrios de la Coruña. La Coruña: Universidade de Coruña, 1997.

GONZÁLEZ-GAUDIANO, E. Hacia un decenio de la Educación para el Desarrollo Sustentable. Rev. Agua y Desarrollo Sustentable, vol.1, n. 5, pp. 16-19. 2003.

Educación ambiental: trayectorias, rasgos y escenarios. México, D.F.: Plaza y Valdés, S.A. de C.V. 2007. 235 p.

GONZÁLEZ-GAUDIANO, E.; LORENZETTI, L. Investigação em educação ambiental na América Latina: mapeando tendências. Educação em Revista, Belo Horizonte, v.25, n.3, p.191-211, dez. 2009. 
GRACE, J. T. G. Tuwharetoa: A history of the Maori people of the Taupo District. Auckland, New Zealand: Reed Books, 1959.

GUIMARÃES, M.A. Educação ambiental crítica. In.: LAYRARGUES, P.P. (Org.). Identidades da educação ambiental brasileira. Brasília: Ministério do Meio Ambiente, p.25-34, 2004b.

HART, P. Transitions in thought and practice: links, divergences and contradictions in post-critical inquiry. Environmental Education Research, vol. 11, n.4, pp. 391-400, 2005.

HARTAS, D. Educational Research and Inquiry: qulitative and quantitative approaches. London: Bloomsbury, 2010.

HIGUCHI, M.I.G.; MAROTI, P. S. Espacialidades e socialidades da educação ambiental além dos muros da escola. Pesquisa em Educação Ambiental, vol. 9, n. 1 - pp. 95-109, 2014.

HUCKLE, J. Realizing sustainability in changing times. In J. Huckle \& S. Sterling (Eds.), Education for Sustainability (pp. 3-17). London: Earthscan publications, 1996.

IARED, V.G.; DI TULLIO, A.; PAYNE, P; OLIVEIRA, H.T. Philosophical Hermeneutics and Critical Pedagogy in Environmental Education Research and Practice. Canadian Journal of Environmental Education, vol. 20, 2015. pp. 124-138.

JENSEN, B. B.; SCHNACK, K. The action competence approach in environmental education. Environmental Education Research, vol. 3, n. 2, pp. 163-179, 1997.

JICKLING, B.;WALS, A. E. J. Globalization and environmental education: looking beyond sustainable development. Journal of Curriculum Studies, vol. 40, no.1, pp. 1-21, 2008.

KORPELA, K.M. Place-identity as a product of environmental self-regulation. Journal of Environmental Psychology, 9, pp. 241-256, 1989.

LAYRARGUES, P.P. Educação para Gestão ambiental: a cidadania no enfrentamento político dos conflitos socioambientais. In: LOUREIRO C.F. B.; LAYRARGUES, P.P.; CASTRO, R.S. (Orgs.). Sociedade e Meio Ambiente: a educação Ambiental em Debate. 6ª ed. São Paulo: Cortez, 2010.

LÓPEZ-CABANAS, M.; CHACÓN, F. Intervención psicosocial y servicios sociales: un enfoque participativo. Madrid: ed. Síntesis psicologia, 2003.

LOUREIRO, C. F. B. Crítica ao teoricismo e ao praticismo na educação ambiental. In: NETO, A. C.; MACEDO FILHO, F. D.; BATISTA, M. S. S. (Orgs.). Educação Ambiental: caminhos traçados, debates políticos e práticas escolares. Brasília: Líber Livro Editora, p. 15-32, 2010.

$\overline{\text { jan/jun., 2004a. }}$

Ambientalismo e lutas sociais no Brasil. Revista Libertas, Juiz de Fora - MG, v.II, n.3,

Educar, participar e transformar em educação ambiental. Revista Brasileira de Educação Ambiental, Brasília, n.0, p.13-20, 2004 b.

LUNDEGARD, I.; WICKMAN, P.O. Conflicts of interest: an indispensable element of education for sustainable development. Environmental Education Research, vol. 13, n. 1, pp. 1-15, 2007.

MADZIMA, L. Shona Hunhu philosophical origins of a successful culture of academic achievement. In O’Donoghue, R.B. Shava, S. and Zazu, C. (Eds.) African Heritage Knowledge in the Context of Social Innovation. Yokohama, UNU-IAS, 2012.

MAQWELANE, N. An exploratory case study of a Foundation Phase learning program to examine how curriculum contextualisation contributes to environmental learning and relevance. Unpublished Half-thesis submitted in partial fulfilment of the requirements for the degree of M.Ed (EE), Rhodes University, 2011.

MILTON, K. Environmentalism and Anthropology. In K. Milton Environmentalism: the view from anthropology. London: Routledge, 1993. 
OLIVEIRA, H.T. Referências históricas e tendências atuais do movimento ambientalista e da educação ambiental em São Carlos, S.P. In: "Encontro Sobre Ambiente e Sociedades: Ações e Políticas Públicas: como as políticas públicas podem ajudar na conservação ambiental e na diminuição das desigualdades de gênero?", São Carlos, EMBRAPA, 22-23/08/2003. Anais... São Carlos: PMSC / SMDS / SMCAS / UNESCO, 2004. pp 20-23.

Metodologias participativas em Educação Ambiental. In: Simpósio Comemorativo dos 10 anos de funcionamento do Curso de Especialização em Educação Ambiental e Recursos Hídricos: perspectivas para o século XXI. São Carlos, 6 a 8 de julho de 2005. Anais, ... São Carlos: CRHEA/SHS/EESC/USP, 2005a, pp. 54-60.

Transdisciplinaridade. In: FERRARO JUNIOR, L.A. (org.) Encontros e Caminhos: formação de educadoras/es ambientais e coletivos educadores. Brasília: Departamento de Educação Ambiental/Ministério do Meio Ambiente. 2005b. pp. 333-343.

Popular education and environmental education in Latin America: converging path and aspirations. In: GONZÁLEZ-GAUDIANO, E. \& PETERS, M. Environmental education: identity, politics and citizenship. 1 ed. Amsterdam: Sense Publishers, 2008, p. 219-230.

PIAGET, J. The Construction of Reality in the Child. New York: Basic Books, 1954.

PROSHANSKY, H., FABIAN A.K.; KAMINOFF, R. Place-identity: Physical word socialization of the self. Journal of the Environmental Psychology, 3, 57-83, 1983.

PUIGGRÓS, A. Historia y prospectiva de la educación popular latinoamericana. In: GADOTTI, M. ; TORRES, C.A. (orgs.) Educação popular: utopia latino-americana. São Paulo: Cortez Editora. 1994.

ROBOTTOM, I., \& HART, P. (1993). Research in environmental education: Engaging the debate. Geelong, Australia: Deakin University Press.

SAMKANGE, S. Hunhuism or Ubuntuism. Salisbury, Zimbabwe/Rhodesia: The Graham, 1980.

SUMNER, J. From Academic Imperialism to the Civil Commons: Institutional Possibilities or Responding to the United Nations Decade of Education of Sustainable Development. Interchange, vol. 39, n. 1, pp. 77-94, 2008.

SUND, P.; WICKMAN, P.-O. Socialization Content in Schools and Education for Sustainable Development - I. A study of Teachers' Selective Traditions. Environmental Education Research, vol. 17, n.5, pp. 599-624, 2011.

TE ARA. Story: Kaitiakitanga - guardianship and conservation Retrieved 17 October, 2015, from http://www.teara.govt.nz/en/kaitiakitanga-guardianship-and-conservation/page-1

THIOLLENT, M. Metodologia da pesquisa-ação. São Paulo: Cortez Editora, 1986.

UNESCO - United Nations Educational, Scientific and Cultural Organisation [UNESCO]. (2014). Sustainable Development Begins with Education. How Education can contribute to the proposed post2015 goals. Paris, UNESCO. Retrieved 22 April 2016, from http://unesdoc.unesco.org/images/0023/002305/230508e.pdf

UNESCO - United Nations Educational, Scientific and Cultural Organisation [UNESCO] (2016). Global Action Programme on ESD. Retrieved from http://en.unesco.org/gap.

VAN BEEK, W.E.A.; BANGA, P.M. The Dogon and Their Trees. In E. Croll and D. Parkin (eds.) Bush Base: Forest Farm. London: Routledge, 1992.

VIEZZER, M. Pequisa-ação-partipante: origens e avanços. In: FERRARO JUNIOR, L.A. (org.) Encontros e Caminhos: formação de educadoras/es ambientais e coletivos educadores. Brasília: Departamento de Educação Ambiental/Ministério do Meio Ambiente. 2005. pp. 277-294.

VIEZZER, M.; OVALLES, O. (orgs.) Manual Latino-Americano de Educação Ambiental. São Paulo: Gaia, 1995. 192 p.

WALS, A.E.J. (ed.) Social learning: towards a sustainable world. The Netherlands: Wageningen Academic Publ., 2007. 
WITTGENSTEIN, L. Philosophical Investigations/Filosofiska undersökningar. Stockholm: Bokförlaget Thales, 1953/1992. 